Research article

urn:lsid:zoobank.org:pub:CF9060EF-84DA-4195-81AE-25B06B69D0DF

\title{
New species of Sericini from Sri Lanka (Coleoptera, Scarabaeidae)
}

\author{
Sasanka RANASINGHE ${ }^{1}$, Jonas EBERLE ${ }^{2}$, Suresh P. BENJAMIN ${ }^{3} \&$ Dirk AHRENS $^{4, *}$ \\ 1,2,3,4 Zoologisches Forschungsmuseum A. Koenig, \\ Adenauerallee 160, D-53113 Bonn, Germany. \\ ${ }^{3}$ National Institute of Fundamental Studies, Hantana Road, 20000 Kandy, Sri Lanka. \\ *Corresponding author: ahrens.dirk_col@gmx.de; d.ahrens@1eibniz-zfmk.de \\ ${ }^{1}$ Email: lakmalisanky@gmail.com \\ ${ }^{2}$ Email: eberle.jonas@gmail.com \\ ${ }^{3}$ Email: suresh.benjamin@gmail.com \\ ${ }^{1}$ urn:1sid:zoobank.org:author:E3B80CA3-910F-4DC0-ACB1-7BBF1B89D923 \\ ${ }^{2}$ urn:1sid:zoobank.org:author:3A048DFB-D6E1-4F17-9705-9B2EB2753B94 \\ ${ }^{3}$ urn:1sid:zoobank.org:author:986CED51-9425-4CB6-84A4-A9464BB9207E \\ ${ }^{4}$ urn:lsid:zoobank.org:author:DEDCE5CF-AA11-4BBF-A2C6-D7C815019714
}

\begin{abstract}
In a recent project, extensive fieldwork was carried out in several parts of Sri Lanka to investigate scarab biodiversity. Here we present the first results of this survey and describe four new Sericini species: Selaserica athukoralai sp. nov., Neoserica dharmapriyai sp. nov., Maladera cervicornis sp. nov., M. galdaththana sp. nov. Further, new locality records for 20 already known species are given. The genitalia and the habitus of all new species are illustrated and photos of the habitats of the new species are given.
\end{abstract}

Keywords. Beetles, chafers, Sri Lanka, taxonomy.

Ranasinghe S., Eberle J., Benjamin S.P. \& Ahrens D. 2020. New species of of Sericini from Sri Lanka (Coleoptera, Scarabaeidae). European Journal of Taxonomy 621: 1-20. https://doi.org/10.5852/ejt.2020.621

\section{Introduction}

After a detailed taxonomic treatment of specimens from numerous museums and private collections, Fabrizi \& Ahrens (2014) documented 77 valid species of Sericini for Sri Lanka. Among them only one species (Maladera rufocuprea Blanchard, 1850) is widely distributed in the Oriental region, while some species are reported as endemic to Southern India and Sri Lanka (e.g., Neoserica sexfoliata Moser, 1915, Selaserica meridionalis Fabrizi \& Ahrens, 2014). However, the majority (67 species) are restricted to Sri Lanka, which suggests that their distribution is likely relative to the ecoclimatic particularities but also due to the long periods of isolation of the island.

The study of Fabrizi \& Ahrens (2014) raised questions on the phylogenetic position of several lineages within Sericini which need to be further explored. In particular the endemic and very likely monophyletic 


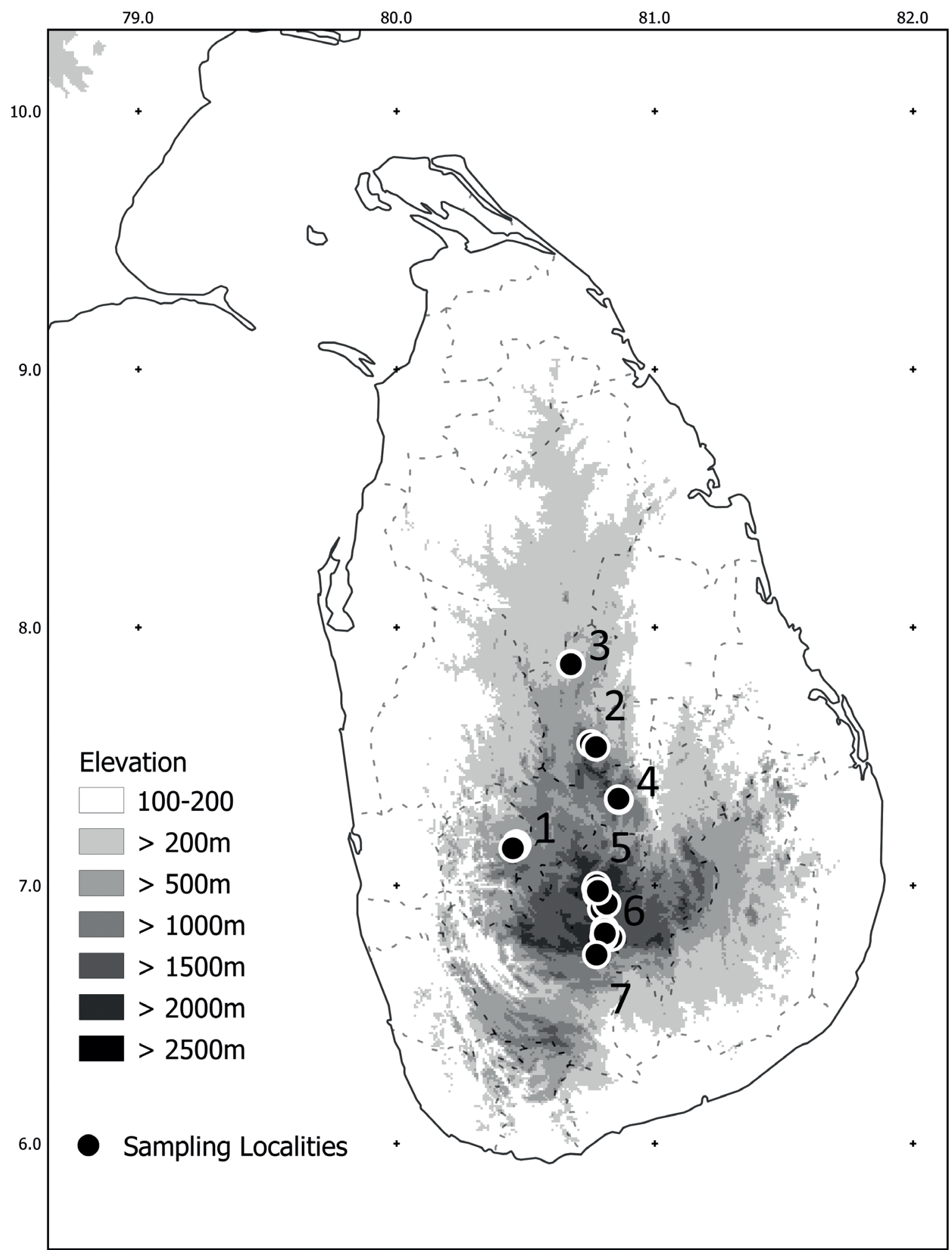

Fig. 1. Map of Sri Lanka showing collecting sites for this study. Numbers refer to major sampling localities. 1 = Aranayake; $2=$ Riverston; 3 = NIFS Arboretum; $4=$ Deenston; $5=$ Nuwara Eliya; $6=$ Horton Plains; 7 = Belihuloya. 
Maladera fistulosa Brenske, 1898 group, characterized by entirely reduced parameres, the Serica fusa Brenske, 1898 group, as well as the genera Periserica Brenske, 1898 and Selaserica Brenske, 1897. The way of choice to resolve this is a thorough phylogenetic analysis of a data matrix that includes the islands scarab biodiversity to the existing molecular data of Eberle et al. (2016) in which endemic taxa of the Indian subcontinent and in particular those from Sri Lanka were underrepresented or missing. Thus, a series of field expeditions to Sri Lanka was initiated in early 2019, with the aim of collecting fresh material for both morphological as well as molecular phylogenetic studies.

Here we present the first results from this fieldwork, describing four new species from Sri Lanka, belonging to the genera Maladera Mulsant \& Rey, 1871, Neoserica Brenske, 1894 and Selaserica, and report new locality records of twenty previously known species.

\section{Material and methods}

Sampling of adult Sericini (Coleoptera: Scarabaeidae) was carried out in seven different localities (Fig. 1) in the Kandy, Matale, Nuwara Eliya and Rathnapura Districts from February to March 2019. Beetles were captured using UV-light traps (Fig. 2A). The traps were placed at a height of approximately $1-2 \mathrm{~m}$ above the ground and positioned at the same spot for $2-3$ consecutive days. A timer activated the light from dusk to midnight (6:00 pm to $11: 00 \mathrm{pm})$. Beetles that were attracted to the light traps were stopped by transparent polystyrene plates $(32 \mathrm{~cm}$ in width) and fell into a container where they were preserved. Whenever the circumstances at the sampling site allowed, we additionally used a LepiLED ${ }^{\circledR}$

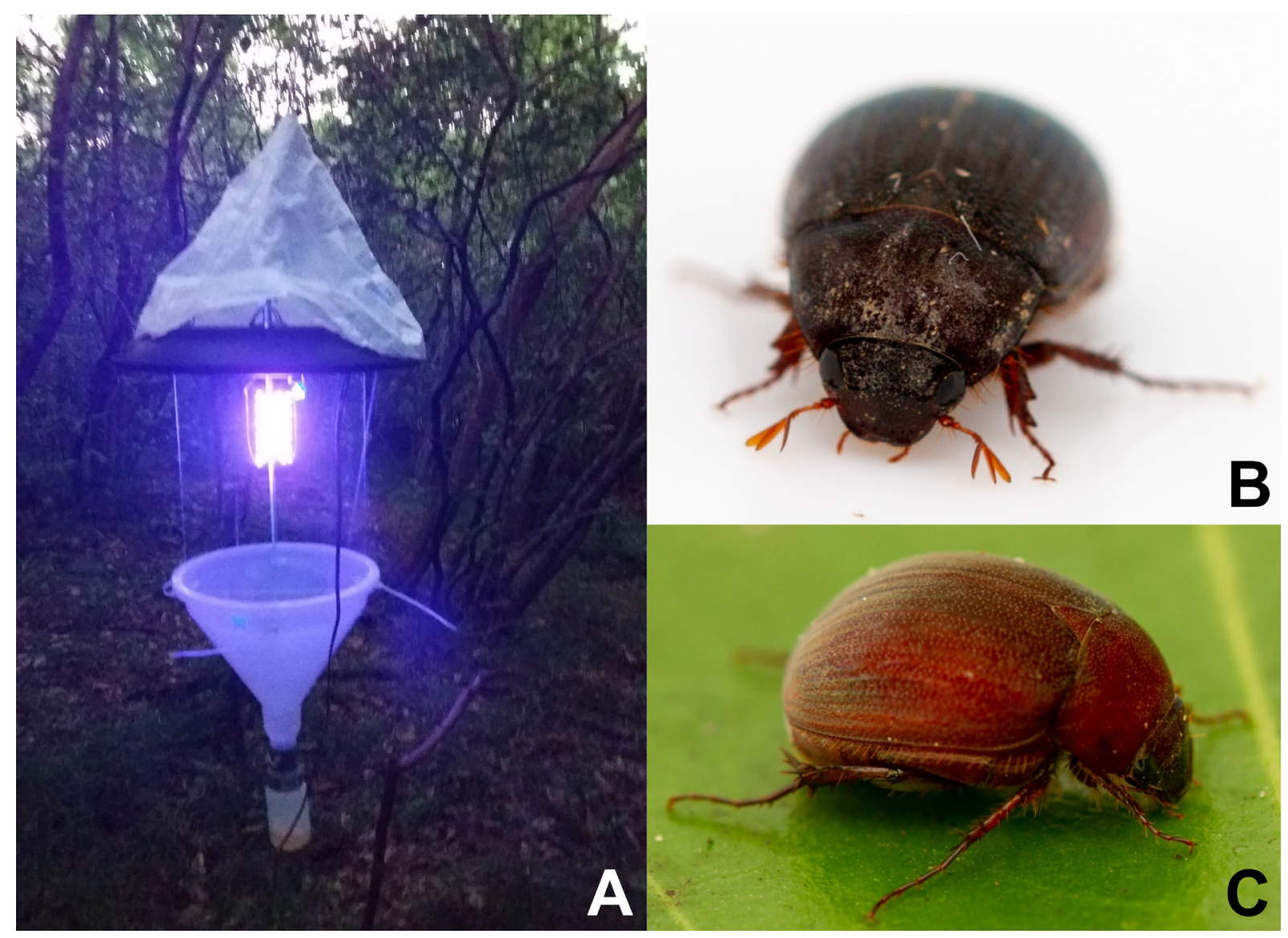

Fig. 2. A. Light trap in the field. B-C. Live Sericini collected from the field. A. Maladera breviatella, male. C. Maladera sp., female. (Photos: J. Eberle). 
lamp (spectrum: mixed radiation) which was placed near a white sheet and manually collected selected Sericini specimens (Fig. 2B-C). Some specimens were hand-collected during the day. All specimens were preserved in vials containing $96 \%$ ethanol.

The specimens were examined under a Wild M3Z stereomicroscope. Male genitalia were dissected and glued to a pointed card. Identification to species level was done using recent literature (Ahrens \& Fabrizi 2016; Fabrizi \& Ahrens 2014) and comparison with type specimens (deposited in ZFMK).

Newly discovered species and their genitalia were photographed using a Zeiss AxioCam HRc camera. Multifocal images were taken using the Zeiss Axio Vision software package, and stacked with Zerene Stacker (http://www.zerenesystems.com) to obtain a single image with the entire area in focus. Maps of sample sites and species distribution were prepared using Quantum GIS 3.6.2 (https://www.qgis.org).

\section{Institutional abbreviations}

ZFMK = Zoological Research Museum A. Koenig, Bonn, Germany

NIFS = National Institute of Fundamental Studies, Kandy, Sri Lanka

SNR = Strict Nature Reserve

FR $\quad=$ Forest Reserve

\section{Results}

Class Insecta Linnaeus, 1758

Subclass Pterygota Lang, 1888

Superfamily Scarabaeoidea Latreille, 1802

Family Scarabaeidae Latreille, 1802

Subfamily Melolonthinae Leach, 1819

Tribe Sericini Kirby, 1837

Genus Selaserica Brenske, 1897

Selaserica athukoralai sp. nov.

urn:1sid:zoobank.org:act:87E36B15-0700-4B33-B079-C12DE755E4E8

Figs $3 \mathrm{~A}-\mathrm{D}, 5 \mathrm{~A}, 6 \mathrm{~A}$

\section{Diagnosis}

Selaserica athukoralai sp. nov. is in shape of aedeagus very similar to Selaserica pusilla Arrow, 1916 and S. splendifica (Brenske, 1898). The new species differs from both latter taxa by the different shape of parameres as well as by the long lateral process on the right apex of the phallobase.

\section{Etymology}

The new species is named after Mr. N.P. Athukorala (NIFS) who supported our expedition in many ways (species name, noun in the genitive case).

\section{Type material}

\section{Holotype}

SRI LANKA - गे; "X-SR0175, Sri Lanka, Matale District, Riverston, Thelgamu oya bangalow, 7.53635607N, 80.77234267E, 509m, Black light, 15-II-2019, Eberle \& Ranasinghe"; ZFMK. 


\section{Description}

MeAsurements. Length: $7.0 \mathrm{~mm}$, length of elytra: $5.2 \mathrm{~mm}$, width: $4.5 \mathrm{~mm}$.

Habitus AND COLORATION. Oval, reddish brown, antenna yellow, dorsal surface shiny and glabrous.

HEAD. Labroclypeus subtrapezoidal, distinctly wider than long, widest at base, lateral margins convex and strongly convergent to blunt anterior angles, lateral border and ocular canthus producing an indistinct blunt angle, margins weakly reflexed, anteriorly distinctly sinuate medially; surface nearly flat, shiny, finely and densely punctate, distance between punctures subequal to their diameter, with a few fine setae anteriorly; frontoclypeal suture feebly impressed and weakly angled medially; smooth area in front of eye approximately twice as wide as long; ocular canthus moderately long and narrow, sparsely punctate, with a single short terminal seta. Frons shiny, with fine, moderately dense punctures, in posterior half impunctate, surface glabrous except for a few setae beside eyes. Eyes moderately large, ratio of diameter/ interocular width: 0.73. Antenna yellowish, with ten antennomeres; club with four antennomeres, 1.2 times as long as remaining antennomeres combined. Mentum elevated and anteriorly flattened.

Pronotum. Moderately wide, widest at posterior third, lateral margins convex and evenly narrowed to the anterior and posterior angles, anterior angles moderately produced and sharp, posterior angle strongly rounded; anterior marginal line narrowly incomplete medially, anterior margin moderately produced medially; surface densely and coarsely punctate, with microscopic setae in the punctures and two long erect setae on each side; anterior and lateral borders sparsely setose, basal margin without marginal line; hypomeron ventrobasally carinate, weakly produced ventrally, on the carina with fine setae. Scutellum small, triangular, dull, with fine and sparse punctures, each bearing a single very minute seta.

ElYTRA. Oblong, widest in posterior third, striae indistinctly impressed, finely and densely punctate, intervals almost flat, with fine, sparse punctures concentrated along the striae, punctures with minute setae, odd intervals with some erect long setae; epipleural edge fine, ending at the convex external apical angle of elytra, epipleura densely setose, apical border broadly membranous.

Ventral surface. Dull, thorax and metacoxa with large and dense punctures, sparsely finely setose, metacoxa glabrous except for numerous short setae laterally; each abdominal sternite with generally distributed fine and dense punctures, each with a moderately long setae, with a transverse row of coarse punctures each bearing a long seta, penultimate sternite apically with a shiny smooth but very short chitinous border. Mesosternum between mesocoxae as wide as mesofemur. Ratio of length of metepisternum/ metacoxa: 1/ 1.1. Pygidium weakly convex, shiny, finely and densely punctate, with a narrow, smooth midline, beside apical border with some long setae.

LEGS. Moderately broad; femur shiny, with two longitudinal rows of setae, finely and sparsely punctate; metafemur almost impunctate, its anterior edge acute, with a very fine, closely adjacent serrated line, anterior longitudinal row of setae not reduced; posterior ventral margin almost straight, weakly widened in apical half, nor ventrally nor dorsally serrated, glabrous. Metatibia moderately broad and long, widest behind middle, dorsal and ventral margins in posterior two thirds subparallel, ratio width/ length: 1/ 3.1, dorsally longitudinally convex, with two groups of spines, basal one at middle, apical one at four fifths of metatibial length, basally beside dorsal margin with a long serrated line, which ends shortly before the middle of metatibia, adjacent to it some single punctures each bearing a single spine; lateral face longitudinally convex, impunctate and glabrous; ventral margin with three fine spines equidistant from each other, medial face smooth, apex interiorly near tarsal articulation shallowly concave, nearly truncate. Tarsomeres impunctate dorsally, ventrally with dense, fine setae; metatarsomeres ventrally with a strongly serrated ridge, beside which is no strong longitudinal carina; first metatarsomere little 
shorter than the two following tarsomeres combined and twice as long as the dorsal tibial spur. Protibia moderately long, tridentate. All claws symmetrical, feebly curved and long, with normally developed basal tooth.

Aedeagus. Fig. 3A-C.

Habitus. Fig. 3D.

\section{Female}

Unknown.

\section{Distribution}

See Fig. 5A.

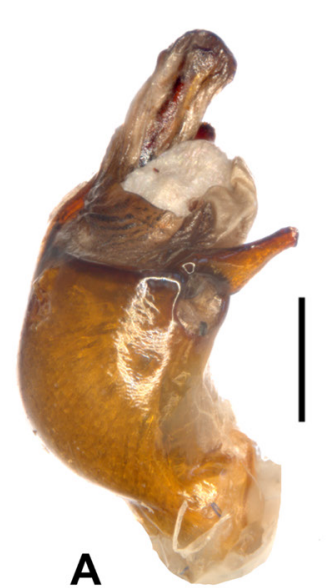

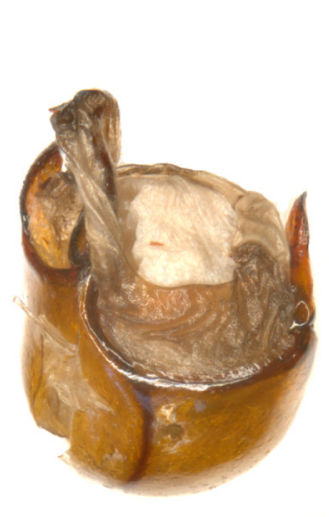

B

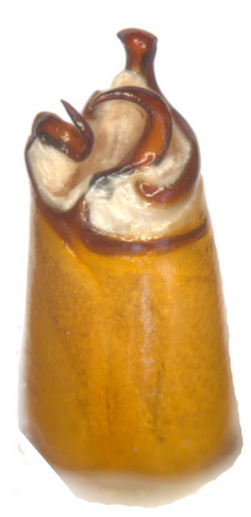

$\mathbf{F}$
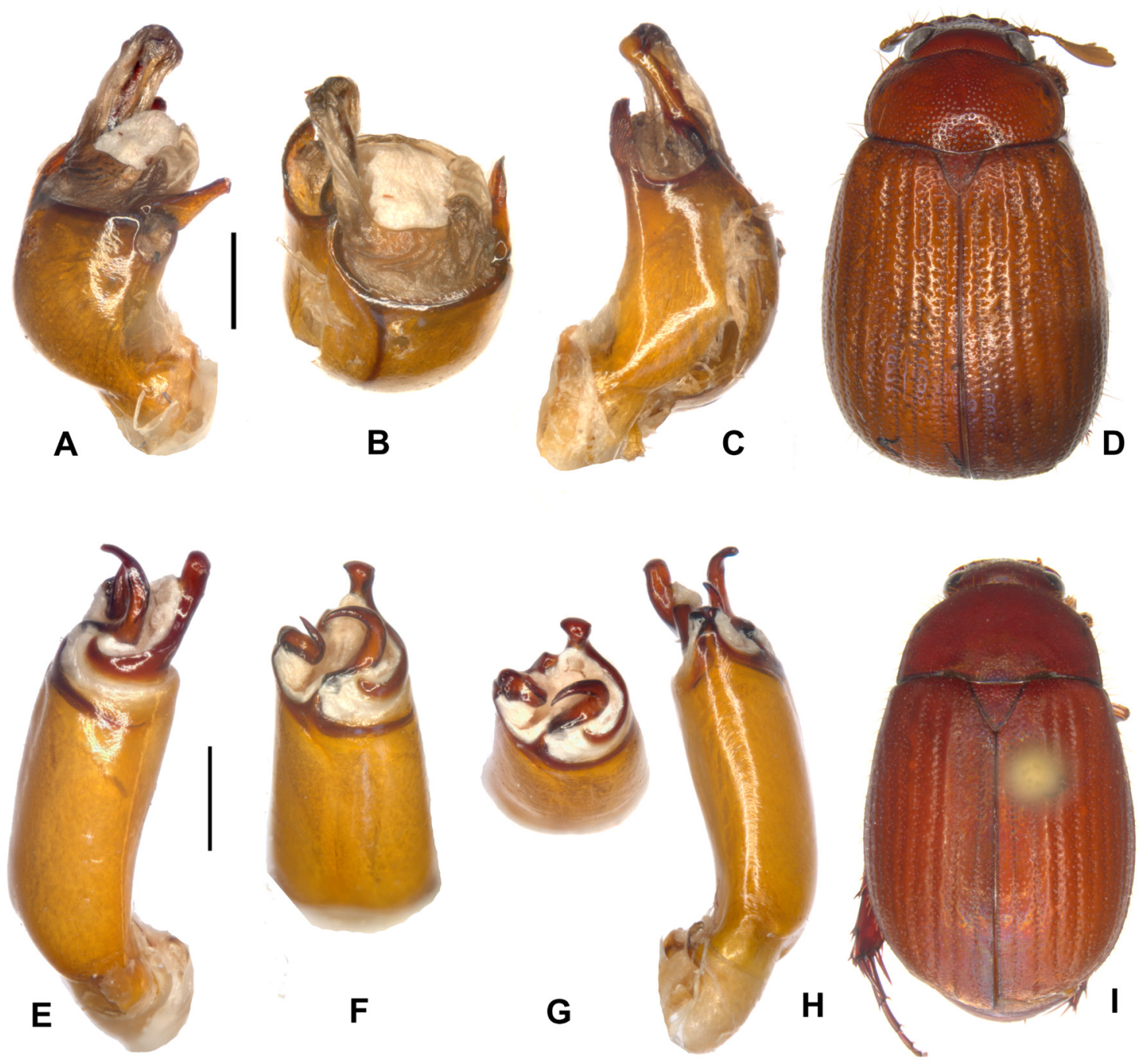

Fig. 3. A-D. Selaserica athukoralai sp. nov. (holotype) E-I. Neoserica dharmapriyai sp. nov. (holotype). A, E. Aedeagus, left side lateral view. C, H. Aedeagus, right side lateral view. B, F-G. Parameres, dorsal view. D, I. Habitus (not to scale). Scales: $0.5 \mathrm{~mm}$. 
Genus Neoserica Brenske, 1894

Neoserica dharmapriyai sp. nov. urn:1sid:zoobank.org:act:5FF85715-9DBB-4148-8B00-6E2B9FE60312

Figs 3E-I, 5B, 6B

\section{Diagnosis}

The new species resembles Neoserica sexfoliata Moser, 1915 in external appearance of the body and in the shape of parameres. Neoserica dharmapriyai sp. nov. may be distinguished from the former by the shorter antennal club being composed of only five antennomeres, and by the shape of parameres: the right paramere is only half as long as the left one, in $N$. sexfoliata both are subequal in length.

\section{Etymology}

The new species is named after Sasanka's husband Prasanna Dharmapriya for his dedication to this project (species name, noun in the genitive case).

\section{Type material examined}

\section{Holotype}

SRI LANKA - Ô; "X-SR0035, Sri Lanka, Kegalle District, Pannala, Galdaththa, Aranayake, 7.16154167N, 80.46388889E, 294m, Black light, 03-III-2019, Eberle \& Ranasinghe"; ZFMK.

\section{Description}

MeAsurements. Length: $7.5 \mathrm{~mm}$, length of elytra: $5.2 \mathrm{~mm}$, width: $4.5 \mathrm{~mm}$.

Habitus And Coloration. Body oval, reddish brown, antenna pale, labroclypeus shiny, dorsal surface dull, except the dense pilosity on head dorsal surface almost glabrous.

HEAD. Labroclypeus broad and subtrapezoidal, widest at base, lateral margins convex and strongly convergent anteriorly, anterior angles including anterior margin strongly rounded, not sinuate medially, all margins strongly reflexed, lateral margins producing a very indistinct angle with the ocular canthus; surface flat, finely and densely punctate, densely erectly setose in coarser punctures mixed with the fine ones; frontoclypeal suture finely incised, not elevated and weakly angled medially; smooth area anterior to eye wide, almost flat, three times as wide as long; ocular canthus long and broad (one third of ocular diameter), coarsely and densely punctate, with a single terminal seta. Frons dull, with fine, moderately dense punctures, with a few erect setae behind the frontoclypeal suture. Eyes moderately large, ratio diameter/ interocular width: 0.66. Antenna with ten antennomeres; club in male with five antennomeres and straight, 0.8 times as long as remaining antennomeres combined. Mentum elevated and slightly flattened anteriorly.

Pronotum. Widely transverse, widest at base, lateral margins in basal half almost straight and slightly convergent anteriorly, in anterior half weakly convex and evenly convergent anteriorly, anterior angles distinctly produced and acute, posterior angles blunt; anterior margin indistinctly produced medially, with a fine and complete marginal line, base of pronotum without marginal line; surface densely and finely punctate, punctures with very minute setae only, otherwise glabrous; lateral and anterior margin densely setose; hypomeron carinate, ventrally slightly produced. Scutellum wide, triangular, at apex moderately pointed, with fine, evenly dense punctures, with only very minute setae.

ELYTRA. Widest at middle, striae finely impressed, finely and moderately densely punctate, intervals weakly convex, with fine and evenly dense punctures, except very minute setae in punctures only a few short setae on lateral odd intervals; epipleural edge robust, ending at strongly curved external apical 
angle of elytra, epipleura densely setose; apical border of elytra with a fine rim of microtrichomes $(100 \times)$.

VENTRAL SURFACE. Dull, coarsely and densely punctate, metepisternum distally impunctate, metasternum sparsely covered with fine, short or very minute setae, metacoxa glabrous, with a few single setae laterally; abdominal sternites finely and densely punctuate, with a transverse row of coarse punctures, each bearing a robust seta, the two basal sternites additionally with dense setae beside the row. Mesosternum between mesocoxae 1.5 times as wide as the width of mesofemur. Ratio of length of metepisternum/ metacoxa: $1 / 1.62$. Pygidium strongly convex at apex and dull, coarsely and densely punctate, without smooth midline, glabrous except some longer setae along the apical margin.

Legs. Broad and moderately long; femur with two longitudinal row of setae, finely and sparsely punctate; metafemur dull, behind the posterior longitudinal row of setae punctures finer and slightly denser, anterior margin acute, without serrated line behind anterior edge, posterior margin smooth ventrally, strongly widened, posterior margin finely serrated over its entire length dorsally, with just a few short setae basally. Metatibia wide and flattened, short, widest at middle of metatibial length, ratio of width/ length: 1/ 2.46, sharply carinate dorsally, with two groups of spines, basal group at first third, apical group at three quarters of metatibial length, basally with a few short robust single spines; lateral face weakly longitudinally convex, finely and sparsely punctate, glabrous, smooth along the middle; ventral margin finely serrated, with four robust equidistant setae; medial face smooth and glabrous; apex finely serrated, interiorly near tarsal articulation weakly concavely sinuate. Tarsomeres dorsally smooth and glabrous, neither laterally nor dorsally carinate, ventrally robustly densely setose; metatarsomeres with a strongly serrated ridge and a smooth subventral longitudinal carina; first metatarsomere slightly shorter than following two tarsomeres combined and slightly longer than dorsal tibial spur. Protibia short, bidentate; anterior claws symmetrical, basal tooth of both claws bluntly truncate at apex.

Aedeagus. Fig. 3E-H.

Habitus. Fig. 3I.

\section{Female}

Unknown.

\section{Distribution}

See Fig. 5B.

Genus Maladera Mulsant \& Rey, 1871

Maladera galdaththana sp. nov. urn:1sid:zoobank.org:act:1A8CD54B-2B9C-4CF1-B424-898A282B389A

Figs 4A-D, 5C, 6C

\section{Diagnosis}

Maladera galdaththana sp. nov. is in shape of aedeagus rather similar to M. woodii Fabrizi \& Ahrens, 2014. The new species differs by the shorter parameres being at base also wider, by the denser long pilosity, and by the extremely long ventral metatibial spur which is apically curved ventrally.

\section{Etymology}

The new species is named after its type locality 'Galdaththa', a small undisturbed forest patch on a rock (adjective in the nominative singular). 


\section{Type material examined}

\section{Holotype}

SRI LANKA - O; "X-SR0036, Sri Lanka, Kegalle District, Pannala, Galdaththa, Aranayake, 7.16154167N, 80.46388889E, 294m, Black light, 03-III-2019, Eberle \& Ranasinghe"; ZFMK.

\section{Paratype}

SRI LANKA - 1 đ̃; "X-SR0093, Sri Lanka, Kegalle District, Alic Land Estate, 7,14420175N, 80,4502789E, 405m, Black light, 04-III-2019, Eberle \& Ranasinghe”; ZFMK.

\section{Description}

MEAsuRements. Length: $7.4 \mathrm{~mm}$, length of elytra: $5.4 \mathrm{~mm}$, width: $4.5 \mathrm{~mm}$.

VARIATION. Length: $7.4-8.2 \mathrm{~mm}$, length of elytra: $5.4-5.6 \mathrm{~mm}$, width: $4.5-4.8 \mathrm{~mm}$.

Habitus AND COlORATION. Body oval, dark brown, antenna dark yellowish, labroclypeus moderately shiny, dorsal surface dull, with fine, sparse erect setae on the head, pronotum, and elytra.

HEAD. Labroclypeus trapezoidal, distinctly wider than long, widest at base, lateral margins convex and strongly convergent to broadly rounded anterior angles, lateral border and ocular canthus produce an indistinct blunt angle, margins weakly reflexed, anteriorly weakly medially; surface weakly convex, moderately shiny, basis narrowly dull, coarsely and densely punctate, distance between punctures less than their diameter, with erect setae in larger punctures; frontoclypeal suture feebly impressed and weakly angled medially; smooth area in front of eye approximately twice as wide as long; ocular canthus moderately long and narrow, finely punctate, with a single short terminal seta. Frons with fine, dense punctures, with dense erect setae being partly bent backwards. Eyes moderately large, ratio of diameter/ interocular width: 0.66 . Antenna yellow, with ten antennomeres; club with three antennomeres, slightly longer than remaining antennomeres combined. Mentum elevated and anteriorly flattened.

Pronotum. Widest at base, lateral margins nearly straight and convergent anteriorly, in anterior third evenly convex and convergent to the anterior angles, anterior angles moderately produced and moderately acute, anterior margin straight, anterior marginal line very fine but complete medially; surface with fine dense punctures mixed with large dense punctures, with fine adpressed white setae in smaller punctures and long erect setae in larger ones; anterior and lateral borders setose, basal margin without marginal line; hypomeron ventrobasally carinate and slightly produced ventrally. Scutellum broad, triangular, with fine and dense punctures each bearing a single fine seta.

ELYTRA. Oblong, widest at middle, striae distinctly impressed, finely and densely punctate, intervals weakly convex, with fine, dense punctures concentrated along striae, with dense short white setae in punctures, odd intervals anteriorly with a few long erect setae; epipleural edge robust, ending at the weakly convex external apical angle of elytra, epipleura densely setose; apical border membranous, apex covered with short microtrichomes.

Ventral surface. Partly dull partly moderately shiny, thorax and metacoxa with large and dense punctures, densely shortly setose, including metacoxa, the latter with numerous long setae laterally; each abdominal sternite, in addition to generally distributed fine and dense punctures with a distinct transverse row of coarse punctures each bearing a short seta, remainder punctures with short white setae, penultimate sternite apically with a shiny smooth chitinous border which is one third as long as sternite. Mesosternum between mesocoxae as wide as mesofemur. Ratio of length of metepisternum/ metacoxa: 1/2.11. Median apophysis of metacoxa with normal fine setae. Pygidium moderately convex, 
coarsely and densely punctate, with a narrow, smooth midline, punctures with short white setae and with numerous erect setae of different length.

LEGS. Wide; femur with two longitudinal rows of setae, finely and densely punctate; metafemur shiny, anterior edge acute, lacking an adjacent serrated line, posterior ventral margin medially feebly concave, strongly widened in apical half and indistinctly serrate apically, dorsally not serrated, glabrous. Metatibia wide and short, widest at middle, ratio width/ length: $1 / 2.1$, dorsally sharply carinate, with two groups of spines, basal one shortly behind middle, apical one at four fifths of metatibial length, basally beside dorsal margin with two robust spines; lateral face longitudinally convex, with dense, fine punctures, along the middle before apex impunctate, with minute setae in punctures; ventral margin with five strong spines equidistant from each other; medial face impunctate, apex interiorly near tarsal articulation shallowly concave. Meso- and metatarsomeres sparsely punctate dorsally and minutely setose, ventrally with sparse, short setae; metatarsomeres ventrally with a strongly serrated ridge, beside which is a strong longitudinal carina; first metatarsomere distinctly longer than following two tarsomeres and slightly shorter than extremely long (as long as metatarsomeres 1 and 2) and apically ventrally curved ventral tibial spur. Protibia short, bidentate. All claws symmetrical, feebly curved and long, with normally developed basal tooth.
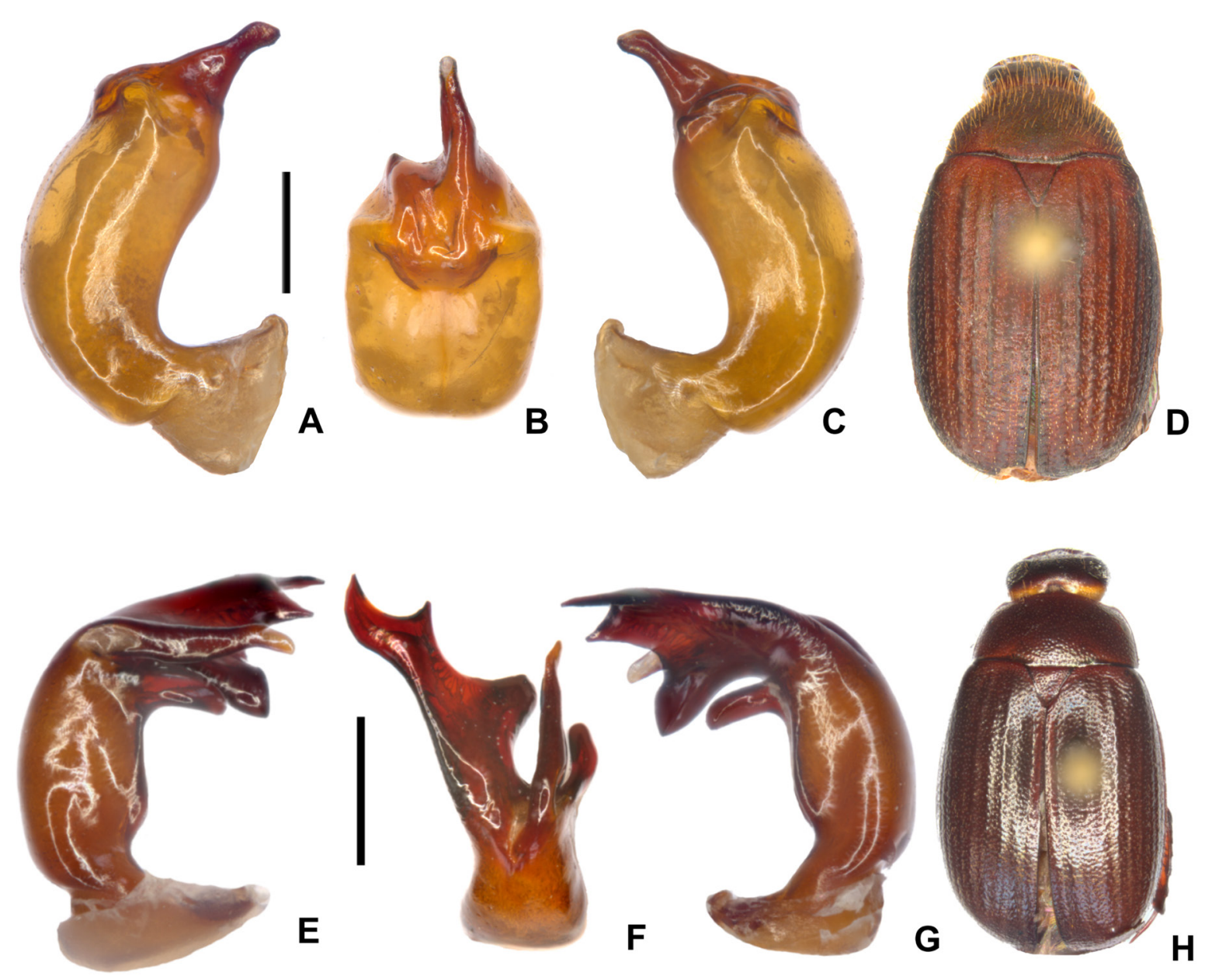

Fig. 4. A-D. Maladera galdaththana sp. nov. (holotype). E-H. M. cervicornis sp. nov. (holotype). A, E. Aedeagus, left side lateral view. C, G. Aedeagus, right side lateral view. B, F. Parameres, dorsal view. D, H. Habitus (not to scale). Scales: $0.5 \mathrm{~mm}$. 
Aedeagus. Fig. 4A-C.

Habitus. Fig. 4D.

Female

Unknown.

\section{Distribution}

See Fig. 5C.

Maladera cervicornis sp. nov.

urn:lsid:zoobank.org:act:8B6DAFF6-F615-4D2E-A776-937A80C0924E

Figs 4E-H, 5D, 6D

\section{Diagnosis}

Maladera cervicornis sp. nov. is in external morphology very similar to M. kandyensis Fabrizi \& Ahrens, 2014. The new species differs by the tubercle on $3^{\text {rd }}$ abdominal sternite as well as by the shape of parameres.

\section{Etymology}

The name of the new species is derived from the combined Latin nouns cornu (horn) and cervus (deer), with reference to the shape of the parameres, resembling the horns of a deer (noun in nominative case).

\section{Type material examined}

\section{Holotype}

SRI LANKA • O’; "X-SR0188, Sri Lanka, Matale District, Riverston, Pitawala Pathana, 7.54976718N, 80.75212294E, 902m, Black light, 15-II-2019, Eberle \& Ranasinghe"; ZFMK.

\section{Paratype}

SRI LANKA • 1 ○े; "X-SR0189, Sri Lanka, Matale District, Riverston, Pitawala Pathana, 7,54976718N, 80,75212294E, 902m, Black light, 15-II-2019, Eberle \& Ranasinghe”; ZFMK.

\section{Description}

MEASUREMENTs. Length: $7.2 \mathrm{~mm}$, length of elytra: $5.4 \mathrm{~mm}$, width: $4.4 \mathrm{~mm}$.

VARIATION. Length: 7.2-7.8 mm, length of elytra: 5.4-5.8 mm, width: 4.4-4.5 mm.

Habitus AND COLORATION. Body short oval, dark brown, antenna yellow, dorsal surface shiny, nearly completely glabrous.

HEAD. Labroclypeus short and rectangular, wider than long, widest at base, lateral margins moderately convex and convergent to broadly rounded anterior angles, lateral border and ocular canthus producing an indistinct blunt angle, margins weakly reflexed, anterior margin almost feebly sinuate medially; surface slightly convex, finely and densely punctate, distance between punctures smaller than their diameter, with numerous erect setae in larger punctures; frontoclypeal suture indistinctly incised and bluntly bent medially; smooth area in front of eye approximately three times as wide as long; ocular canthus long and narrow, minutely and superficially punctate, without a single short terminal seta. Frons with fine, dense punctures, with a few long erect setae in larger punctures. Eyes very large, ratio of diameter/ 
interocular width: 0.97. Antenna yellow, with ten antennomeres; club with three antennomeres, as long as remaining antennomeres combined. Mentum elevated and anteriorly flattened.

Pronotum. Wide, widest at base, lateral margins weakly convex and evenly narrowed to the anterior angles, anterior angles moderately produced and sharp, anterior marginal line very fine but complete medially, anterior margin straight; surface finely densely punctate, except a few short and fine setae laterally glabrous; anterior and lateral borders setose, basal margin without marginal line; hypomeron ventrobasally carinate and slightly produced ventrally. Scutellum short and broad, triangular, with fine and dense punctures, glabrous.

ELYTRA. Short oval, widest shortly behind middle, striae distinctly impressed, finely and densely punctate, intervals weakly convex, with moderately fine, dense punctures and with dense, fine, short setae; epipleural edge fine, ending at the weakly convex external apical angle of elytra, epipleura densely setose; apical border narrowly membranous, apex covered with short microtrichomes.

Ventral SURFACE. Shiny, thorax and metacoxa with large and dense punctures, sparsely setose, metacoxa with minute adjacent setae in the punctures except for numerous long setae laterally, apical margin weakly convex, without a broad rim of long white microtrichomes; each abdominal sternite, in addition to evenly distributed fine and dense punctures bearing each a fine seta, with a distinct transverse row of coarse punctures each bearing a long and more robust seta, $3^{\text {rd }}$ sternite with a sharp median tubercle being half as high as sternite length, penultimate sternite apically with a shiny smooth chitinous border, which is a quarter as long as the sternite. Mesosternum between mesocoxae as wide as mesofemur, with a semi-circular ridge bearing robust setae. Ratio of length of metepisternum/ metacoxa: 1/ 1.89. Pygidium moderately convex, moderately finely and densely punctate, without smooth midline, punctures with short and moderately dense, adjacent setae or with moderately dense, long, erect setae.

LEGS. Short and wide; femur with two longitudinal rows of setae, finely and densely punctate; metafemur shiny, anterior edge acute, lacking an adjacent serrated line, ventral surface densely punctate and setose, posterior ventral margin straight, only little widened in apical half, finely serrate apically, dorsally not serrated, glabrous. Metatibia short, widest at middle, posteriorly only very little narrowed, ratio width/ length: $1 / 2.87$, dorsally sharply carinate, with two groups of spines, basal one at middle, apical one at three quarters of metatibial length, basally beside dorsal margin with two single punctures with serrated margins, each bearing a single robust spine and beside them a longitudinal serrated line; lateral face almost flat, with dense, large but superficial punctures and with minute setae in the punctures; ventral margin with four strong spines equidistant from each other, medial face smooth, apex interiorly near tarsal articulation shallowly concave. Meso- and metatarsomeres finely and sparsely punctate but glabrous dorsally, ventrally with sparse, short setae; metatarsomeres ventrally with a strongly serrated ridge, beside which is a strong longitudinal carina; first metatarsomere as long as following two tarsomeres combined and as long as dorsal tibial spur. Protibia short, bidentate. All claws symmetrical, feebly curved and long, with normally developed basal tooth.

Aedeagus. Fig. 4E-G.

Habitus. Fig. 4H.

\section{Female}

Unknown.

\section{Distribution}

See Fig. 5D. 


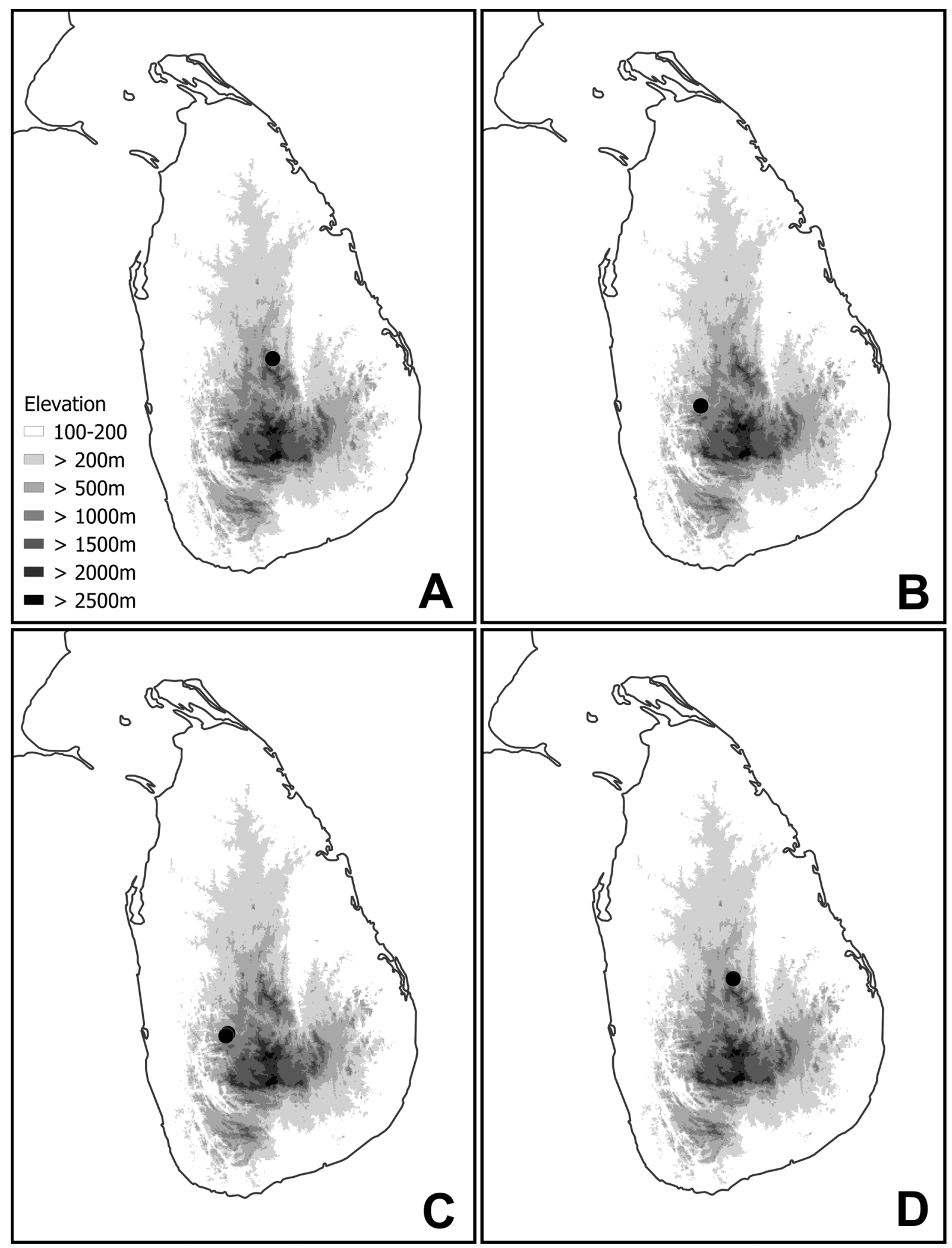

Fig. 5. Distribution of the new species. A. Selaserica athukoralai sp. nov. B. Neoserica dharmapriyai sp. nov. C. Maladera galdaththana sp. nov. D. M. cervicornis sp. nov. 

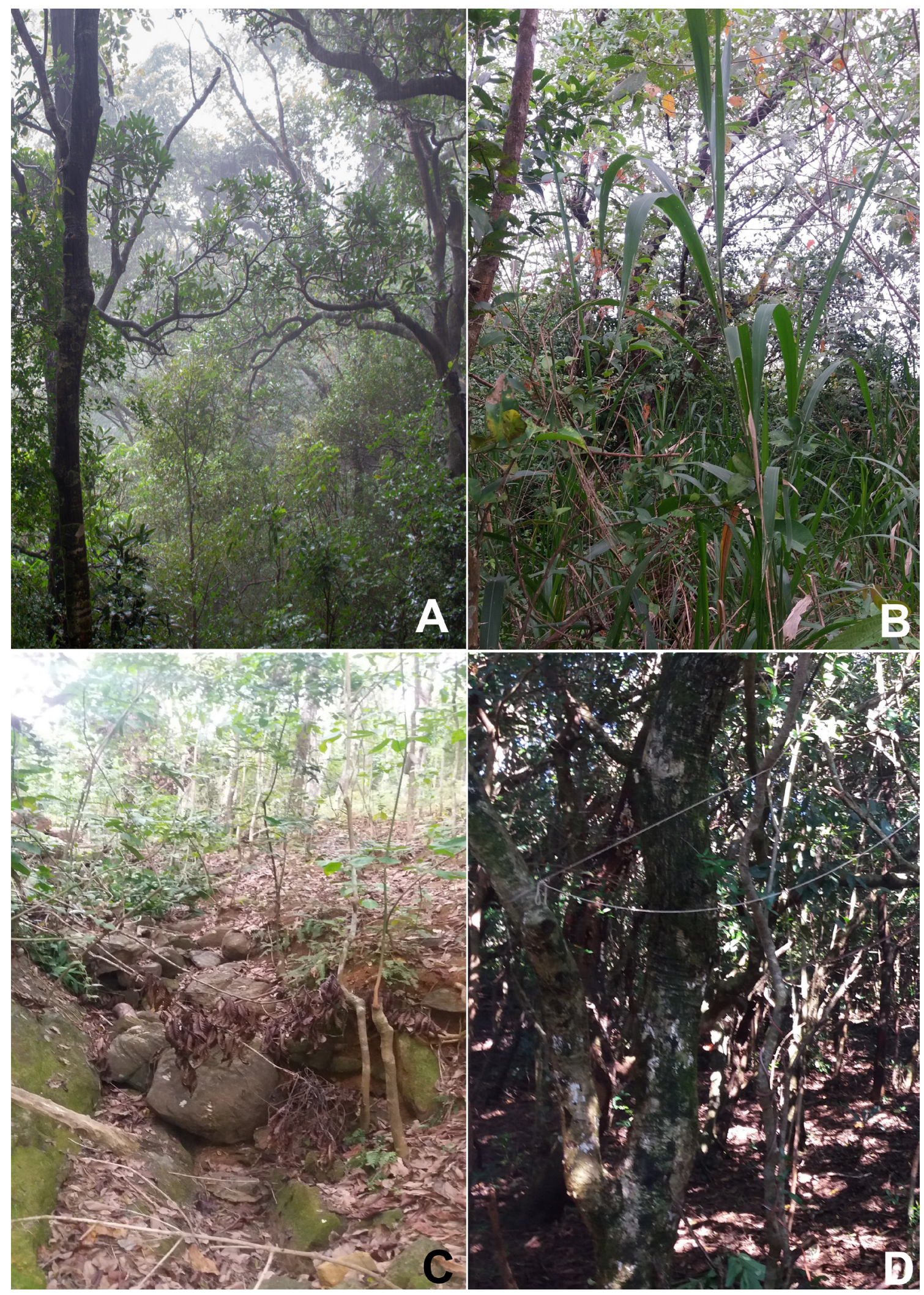

Fig. 6. Photos of the habitats of the new species. A. Selaserica athukoralai sp. nov. B. Neoserica dharmapriyai sp. nov. B-C. Maladera galdaththana sp. nov. D. M. cervicornis sp. nov. 


\section{New distribution records}

Maladera badullana Fabrizi \& Ahrens, 2014

\section{Material examined}

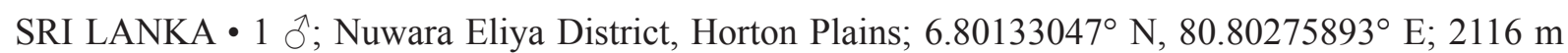

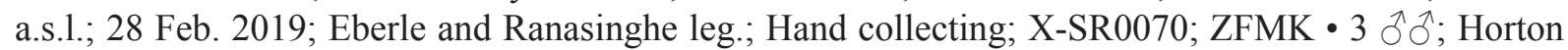
Plains; $6.81278056^{\circ} \mathrm{N}, 80.80444444^{\circ} \mathrm{E} ; 2147 \mathrm{~m}$ a.s.1.; 26 Feb. 2019; Eberle and Ranasinghe leg.; Black light; X-SR0179 to X-SR0181; ZFMK • 1 万̊; Horton Plains; $6.81437222^{\circ} \mathrm{N}, 80.80638889^{\circ} \mathrm{E} ; 2146 \mathrm{~m}$ a.s.1.; 28 Feb. 2019; Eberle and Ranasinghe leg.; Light sheet; X-SR0121; ZFMK • 1 §ं; Horton Plains; $6.82978333^{\circ} \mathrm{N}, 80.80611111^{\circ} \mathrm{E} ; 2154 \mathrm{~m}$ a.s.l.; 26 Feb. 2019; Eberle and Ranasinghe leg.; Black light;

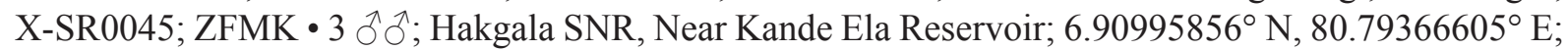
1917 m a.s.l.; 24 Feb. 2019; Eberle and Ranasinghe leg.; Black light; X-SR0075 to X-SR0077; NIFS - 9 ô ô; Hakgala SNR, Near Kande Ela Reservoir; 6.91085232 ${ }^{\circ}$ N, $80.79427602^{\circ}$ E; 1914 m a.s.1.; $23-24$ Feb. 2019; Eberle and Ranasinghe leg.; Black light; X-SR0011 to X-SR0014; X-SR0027 to X-SR0028,

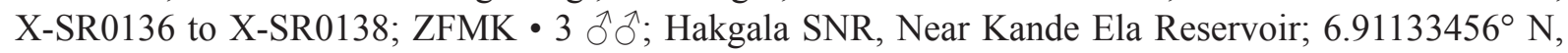
80.79475087 ${ }^{\circ}$ E; 1907 m a.s.1.; 23 Feb. 2019; Eberle and Ranasinghe leg.; Black light; X-SR0020,

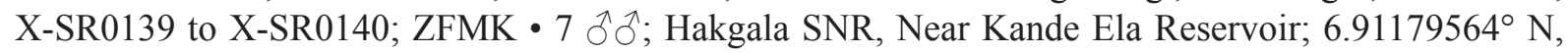
80.79491161 ${ }^{\circ}$ E; $1882 \mathrm{~m}$ a.s.1.; 23-24 Feb. 2019; Eberle and Ranasinghe leg.; Black light; X-SR0004 to X-SR0006, X-SR0103 to X-SR0104, X-SR0176, X-SR0178; ZFMK・ 1 đ ; Hakgala SNR, Seetha Eliya; 6.9304544 ${ }^{\circ} \mathrm{N}, 80.81356983^{\circ} \mathrm{E} ; 1789 \mathrm{~m}$ a.s.l; 24 Feb. 2019; Eberle and Ranasinghe leg.; Black light; X-SR0001; ZFMK • 4 ô ơ; Hakgala SNR, Seetha Eliya; $6.93074021^{\circ} \mathrm{N}, 80.8134195^{\circ} \mathrm{E} ; 1773 \mathrm{~m}$ a.s.l.; 24 Feb. 2019; Eberle and Ranasinghe leg.; Black light; X-SR0067, X-SR0129, X-SR0159, X-SR0163; ZFMK • $2{ }^{\wedge}{ }^{\lambda}$; Galways Land NP; $6.96616216^{\circ} \mathrm{N}, 80.77744079^{\circ}$ E; $1931 \mathrm{~m}$ a.s.1.; 23 Feb. 2019; Eberle and Ranasinghe leg.; Black light; X-SR0048 to X-SR0049; ZFMK • 1 o; Galways Land NP; 6.96747401 ${ }^{\circ} \mathrm{N}, 80.77677784^{\circ}$ E; 1982 m a.s.l.; 23 Feb. 2019; Eberle and Ranasinghe leg.; Black light;

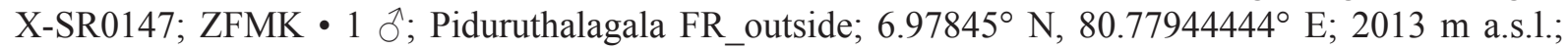

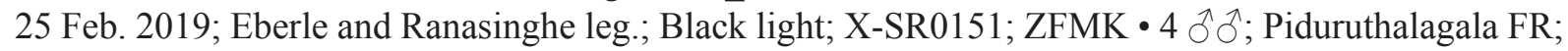
6.98299444 ${ }^{\circ} \mathrm{N}, 80.77305556^{\circ} \mathrm{E} ; 2073 \mathrm{~m}$ a.s.1.; $25 \mathrm{Feb}$. 2019; Eberle and Ranasinghe leg.; Black light; X-SR0126, X-SR0128, X-SR0148, X-SR0150; ZFMK • $2 \partial^{\lambda} \sigma^{\top}$; Piduruthalagala FR; $6.98955278^{\circ} \mathrm{N}$, 80.77138889 ${ }^{\circ}$ E; 2192 m a.s.l.; 25 Feb. 2019; Eberle and Ranasinghe leg.; Black light; X-SR0022 to X-SR0023; ZFMK.

\section{Material examined}

\section{Maladera breviatella Fabrizi \& Ahrens, 2014}

SRI LANKA 11 ' ; Matale District, Dambulla, NIFS Arboretum; $7.85783259^{\circ} \mathrm{N}, 80.67391938^{\circ} \mathrm{E} ; 167 \mathrm{~m}$ a.s.1.; 17 Feb. 2019; Eberle and Ranasinghe leg.; Black light; X-SR0030; ZFMK • 1 ; ; Dambulla, NIFS Arboretum; 7.86011766 ${ }^{\circ}$ N, 80.67441844 ${ }^{\circ}$ E; 187 m a.s.1.; 16 Feb. 2019; Eberle and Ranasinghe leg.;

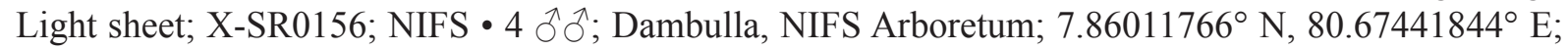
187 m a.s.l.; 17 Feb. 2019; Eberle and Ranasinghe leg.; Light sheet; X-SR0051 to X-SR0054; ZFMK.

\section{Material examined}

Maladera calcarata (Brenske, 1898)

SRI LANKA • 1 đ̊; Matale District, Dambulla, NIFS Arboretum; $7.85766783^{\circ} \mathrm{N}, 80.67474244^{\circ} \mathrm{E}$; 174 m a.s.1.; 16 Feb. 2019; Eberle and Ranasinghe leg.; Black light; X-SR0086; ZFMK・ 1 ô; Dambulla, NIFS Arboretum; $7.85783259^{\circ}$ N, $80.67391938^{\circ}$ E; 167 m; 18 Feb. 2019; Eberle and Ranasinghe leg.; Black light; X-SR0142; NIFS • 1 `̊; Dambulla, NIFS Arboretum; $7.85897387^{\circ} \mathrm{N}, 80.67533196^{\circ} \mathrm{E}$; 203 m a.s.l.; 16 Feb. 2019; Eberle and Ranasinghe leg.; Black light; X-SR0100; ZFMK. 


\section{Material examined}

Maladera cinnaberina (Brenske, 1898)

SRI LANKA -1 đo ; Kegalle District, Aranayake, near tea estate; $7.15068199^{\circ} \mathrm{N}, 80.46286137^{\circ} \mathrm{E}$; 252 m a.s.1.; 3 Mar. 2019; Eberle and Ranasinghe leg.; Black light net; X-SR0094; ZFMK 1 ô; Pannala, Polwaththa, Aranayake; 7.15828056 ${ }^{\circ}$ N, 80.46666667 E; 238 m a.s.1.; 3 Mar. 2019; Eberle and Ranasinghe leg.; Black light; X-SR0155; ZFMK.

\section{Material examined}

Maladera coxalis (Moser, 1915)

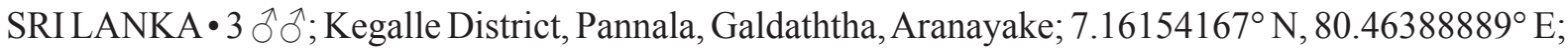
294 m a.s.1.; 3 Mar. 2019; Eberle and Ranasinghe leg.; Black light; X-SR0096, X-SR0132 to X-SR0133; ZFMK.

\section{Material examined}

Maladera dubia (Arrow, 1916)

SRI LANKA • 2 ふぇ; Nuwara Eliya District, Horton Plains; $6.80133047^{\circ} \mathrm{N}, 80.80275893^{\circ} \mathrm{E} ; 2116 \mathrm{~m}$ a.s.l.; 28 Feb. 2019; Eberle and Ranasinghe leg.; Hand collecting; X-SR0069, X-SR0071; NIFS • 1 ○; Horton Plains; 6.81437222 ${ }^{\circ} \mathrm{N}, 80.80638889^{\circ}$ E; 2146 m a.s.1.; 28 Feb. 2019; Eberle and Ranasinghe leg.; Light sheet; X-SR0120; ZFMK • 6 วิ ô; Horton Plains; $6.82978333^{\circ} \mathrm{N}, 80.80611111^{\circ} \mathrm{E} ; 2154 \mathrm{~m}$ a.s.1.; 26 Feb. 2019; Eberle and Ranasinghe leg.; Black light; X-SR0046 to X-SR0047, X-SR0063 to X-SR0065, X-SR0168; ZFMK • 1 đ̊; Hakgala SNR, Near Kande Ela Reservoir; 6.91179564 N, 80.79491161 ${ }^{\circ}$ E; $1882 \mathrm{~m}$ a.s.l.; 23 Feb. 2019; Eberle and Ranasinghe leg.; Black light; X-SR0177;

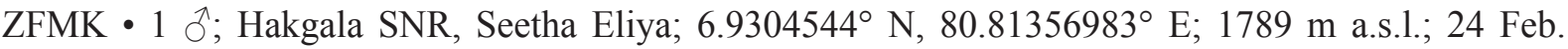
2019; Eberle and Ranasinghe leg.; Black light; X-SR0025; ZFMK • 2 ๙ึં ; Hakgala SNR, Seetha Eliya; $6.93074021^{\circ} \mathrm{N}, 80.8134195^{\circ} \mathrm{E} ; 1773 \mathrm{~m}$ a.s.l.; 24 Feb. 2019; Eberle and Ranasinghe leg.; Black

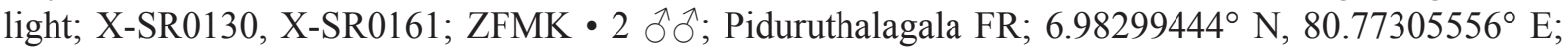
2073 m a.s.l.; 25 Feb. 2019; Eberle and Ranasinghe leg.; Black light; X-SR0127, X-SR0149; ZFMK

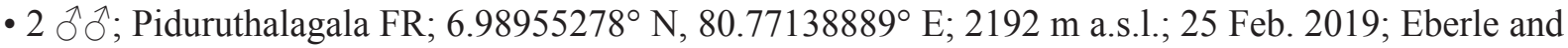
Ranasinghe leg.; Black light; X-SR0184 to X-SR0185; ZFMK.

\section{Material examined}

Maladera fistulosa (Brenske, 1898)

SRI LANKA • 1 o ; Nuwara Eliya District, Hakgala SNR, Seetha Eliya; $6.9304544^{\circ} \mathrm{N}, 80.81356983^{\circ} \mathrm{E}$;

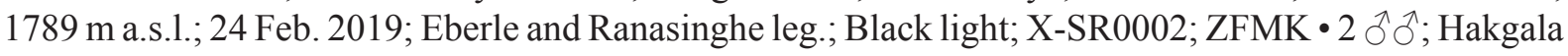
SNR, Seetha Eliya; $6.93074021^{\circ}$ N, $80.8134195^{\circ}$ E; 1773 m a.s.1.; 24 Feb. 2019; Eberle and Ranasinghe leg.; Black light; X-SR0160, X-SR0162; ZFMK.

\section{Material examined}

\section{Maladera heveli Fabrizi \& Ahrens, 2014}

SRI LANKA • 1 ○ं; Matale District, Dambulla, NIFS Arboretum; $7.85766783^{\circ} \mathrm{N}, 80.67474244^{\circ} \mathrm{E}$; 174 m a.s.1.; 18 Feb. 2019; Eberle and Ranasinghe leg.; Black light; X-SR0090; ZFMK. 


\section{Material examined}

Maladera hortonensis Fabrizi \& Ahrens, 2014

SRI LANKA • 2 o $^{\Uparrow}$; Nuwara Eliya District, Horton Plains; $6.80735^{\circ} \mathrm{N}, 80.80472222^{\circ} \mathrm{E} ; 2138 \mathrm{~m}$ a.s.1.; 26 Feb. 2019; Eberle and Ranasinghe leg.; Black light; X-SR0007 to X-SR0008; ZFMK • 1 o ; Horton Plains; $6.82978333^{\circ} \mathrm{N}, 80.80611111^{\circ} \mathrm{E} ; 2154 \mathrm{~m}$ a.s.1.; 26 Feb. 2019; Eberle and Ranasinghe leg.; Black light; X-SR0170; ZFMK • 1 `’; Piduruthalagala FR; $6.98955278^{\circ} \mathrm{N}, 80.77138889^{\circ} \mathrm{E} ; 2192 \mathrm{~m}$ a.s.1.;

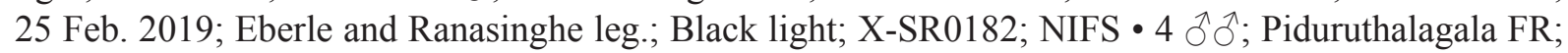
7.00029167 ${ }^{\circ}$ N, $80.77527778^{\circ}$ E; 2483 m a.s.l.; 25 Feb. 2019; Eberle and Ranasinghe leg.; Black light; X-SR0083, X-SR0085, X-SR0167, X-SR0040; ZFMK.

\section{Material examined}

Maladera lindulana Fabrizi \& Ahrens, 2014

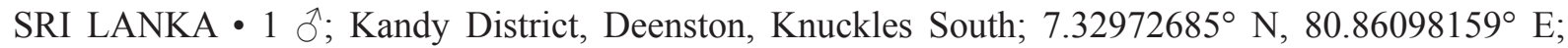
1169 m a.s.1.; 21 Feb. 2019; Eberle and Ranasinghe leg.; Black light; X-SR0108; ZFMK • 1 万ै; Deenston, Knuckles South; 7.32991027 N, 80.86093445 E; $1142 \mathrm{~m}$ a.s.1.; 20 Feb. 2019; Eberle and Ranasinghe leg.; Light sheet; X-SR0106; ZFMK • 1 of; Deenston, Knuckles South; $7.33077851^{\circ} \mathrm{N}$, 80.86049097 ${ }^{\circ}$ E; 1156 m a.s.1.; 19 Feb. 2019; Eberle and Ranasinghe leg.; Black light; X-SR0174;

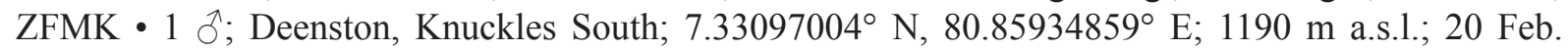
2019; Eberle and Ranasinghe leg.; Black light; X-SR0055; ZFMK • 1 §̊; Deenston, Knuckles South; 7.33616555 ${ }^{\circ} \mathrm{N}, 80.85907541^{\circ}$ E; 1197 m a.s.1.; 21 Feb. 2019; Eberle and Ranasinghe leg.; Black light; X-SR0123; NIFS.

\section{Material examined}

Maladera pubescens (Arrow, 1916)

SRI LANKA 2 ○ें; Kegalle District, Pannala, Galdaththa, Aranayake; $7.16154167^{\circ} \mathrm{N}, 80.46388889^{\circ} \mathrm{E}$; 294 m a.s.1.; 3 Mar. 2019; Eberle and Ranasinghe leg.; Black light; X-SR0037, X-SR0097; ZFMK.

\section{Material examined}

Maladera rotundata (Walker, 1859)

SRI LANKA • 1 §̊; Kegalle District, Pannala, Galdaththa, Aranayake; $7.16154167^{\circ}$ N, $80.46388889^{\circ}$ E; 294 m a.s.1.; 3 Mar. 2019; Eberle and Ranasinghe leg.; Black light; X-SR0134; ZFMK.

\section{Material examined}

Maladera rufocuprea (Blanchard, 1850)

SRI LANKA • $1{ }^{\top}$; Ratnapura District, Belihuloya; $6.731762^{\circ} \mathrm{N}, 80.773989^{\circ} \mathrm{E} ; 750 \mathrm{~m}$ a.s.1.; 1 Mar. 2019; Eberle and Ranasinghe leg.; Black light; X-SR0158; ZFMK • 1 đ; Kegalle District, Aranayake, near tea estate; $7.15050176^{\circ} \mathrm{N}, 80.46239683^{\circ} \mathrm{E} ; 245 \mathrm{~m}$ a.s.1.; 12 Feb. 2019; Eberle and \& Ranasinghe

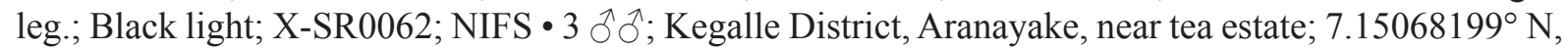
$80.46286137^{\circ}$ E; $252 \mathrm{~m}$ a.s.1.; 10 Feb. 2019; Eberle and Ranasinghe leg.; Black light; X-SR0080 to X-SR0082; ZFMK.

\section{Material examined}

\section{Maladera weligamana (Brenske, 1900)}

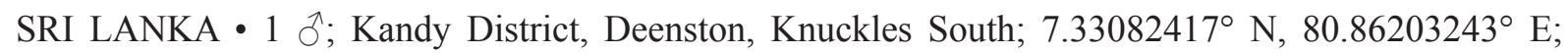
1108 m a.s.l.; 20 Feb. 2019; Eberle and Ranasinghe leg.; Black light; X-SR0187; ZFMK. 


\section{Material examined}

Selaserica maculicauda (Arrow, 1916)

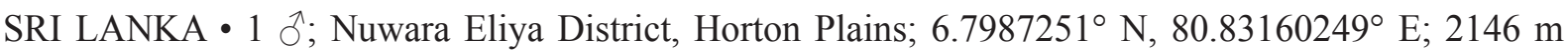
a.s.1.; 27 Feb. 2019; Eberle and Ranasinghe leg.; Black light; X-SR0145; ZFMK.

\section{Material examined}

\section{Selaserica nitida (Candèze, 1861)}

SRI LANKA • 1 O$^{\Uparrow}$; Nuwara Eliya District, Hakgala SNR, Seetha Eliya; $6.92999891^{\circ}$ N, $80.81359713^{\circ}$ E; 1794 m a.s.l.; 24 Feb. 2019; Eberle and Ranasinghe leg.; Black light; X-SR0119; ZFMK.

\section{Material examined}

Selaserica pusilla Arrow, 1916

SRI LANKA • 1 ○َ; Matale District, Dambulla, NIFS Arboretum; $7.85897387^{\circ} \mathrm{N}, 80.67533196^{\circ} \mathrm{E}$; 203 m a.s.l.; 16 Feb. 2019; Eberle and Ranasinghe leg.; Black light; X-SR0101; ZFMK.

\section{Material examined}

Neoserica sexfoliata Moser, 1915

SRI LANKA • $1 \partial^{\top}$; Matale District, Dambulla, NIFS Arboretum; $7.86011766^{\circ} \mathrm{N}, 80.67441844^{\circ} \mathrm{E}$; 187 m a.s.l.; 18 Feb. 2019; Eberle and Ranasinghe leg.; Light sheet; X-SR0115; ZFMK.

\section{Material examined}

Serica fusa Brenske, 1898

SRI LANKA • 3 ○ึ ; Nuwara Eliya District, Horton Plains; $6.81278056^{\circ} \mathrm{N}, 80.80444444^{\circ} \mathrm{E} ; 2147 \mathrm{~m}$

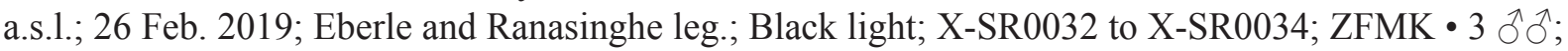
Hakgala SNR, Near Kande Ela Reservoir; 6.90995856 N, 80.79366605 E; 1917 m a.s.l.; 24 Feb.

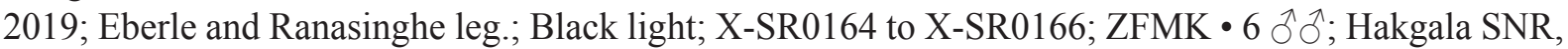
Near Kande Ela Reservoir; 6.91085232 ${ }^{\circ}$ N, 80.79427602 ${ }^{\circ}$ E; 1914 m a.s.1.; 23-24 Feb. 2019; Eberle

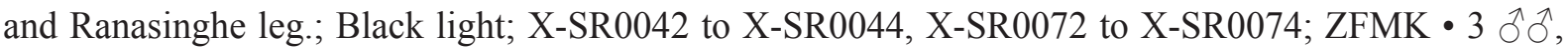
1 †; Hakgala SNR, Near Kande Ela Reservoir; 6.91133456 N, 80.79475087 E; 1907 m a.s.1.; 23 Feb. 2019; Eberle and Ranasinghe leg.; Black light; X-SR0141, X-SR0171 to X-SR0173; ZFMK • 2 ठ ठే; Hakgala SNR, Near Kande Ela Reservoir; 6.91179564 N, 80.79491161 ${ }^{\circ}$ E; 1882 m a.s.1.; 23-24 Feb. 2019; Eberle and Ranasinghe leg.; Black light; X-SR0091, X-SR0152; NIFS • 2 ơ ठे; Hakgala SNR, Seetha Eliya; 6.92999891 ${ }^{\circ} \mathrm{N}, 80.81359713^{\circ}$ E; 1794 m a.s.l.; 24 Feb. 2019; Eberle and Ranasinghe leg.; Black light; X-SR0153 to X-SR0154; ZFMK • 1 đo; Hakgala SNR, Seetha Eliya; $6.93074021^{\circ} \mathrm{N}$, 80.8134195 ${ }^{\circ}$ E; 1773 m a.s.1.; 24 Feb. 2019; Eberle and Ranasinghe leg.; Black light; X-SR0068; ZFMK

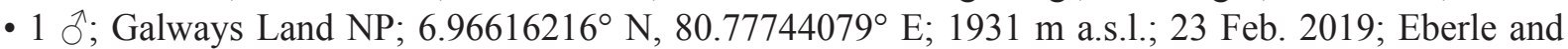

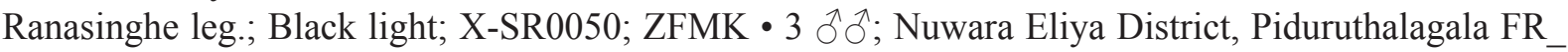
outside; $6.97845^{\circ} \mathrm{N}, 80.77944444^{\circ} \mathrm{E} ; 2013 \mathrm{~m}$ a.s.1.; 25 Feb. 2019; Eberle and Ranasinghe leg.; Black light; X-SR0059 to X-SR0061; ZFMK • 1 ơ; Piduruthalagala FR; $6.98955278^{\circ} \mathrm{N}, 80.77138889^{\circ} \mathrm{E}$; 2192 m a.s.l.; 25 Feb. 2019; Eberle and Ranasinghe leg.; Black light; X-SR0058; ZFMK.

\section{Material examined}

Serica lurida Brenske, 1898

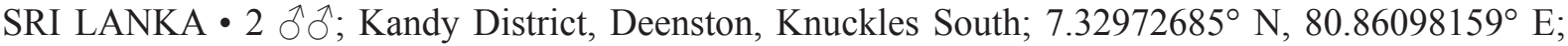
1169 m a.s.l.; 21 Feb. 2019; Eberle and Ranasinghe leg.; Black light; X-SR0109 to X-SR0110; ZFMK 


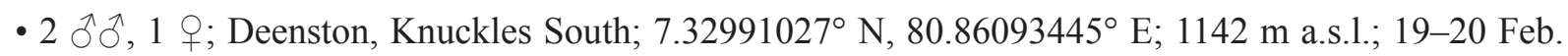
2019; Eberle and Ranasinghe leg.; Light sheet; X-SR0098 to X-SR0099, X-SR0107; ZFMK • 1 ○; Deenston, Knuckles South; 7.33097004 N, 80.85934859 E; 1190 m a.s.1.; 20 Feb. 2019; Eberle and Ranasinghe leg.; Black light; X-SR0056; ZFMK • 1 ; ; Deenston, Knuckles South; 7.33616555 ${ }^{\circ}$, 80.85907541 ${ }^{\circ}$ E; 1197 m a.s.1.; 21 Feb. 2019; Eberle and Ranasinghe leg.; Black light; X-SR0125; NIFS.

\section{Discussion}

This first supplement to the monograph of Sericini of the Sri Lanka (Fabrizi \& Ahrens 2014), that includes the description of four new species, revealed furthermore the high amount of endemism of the subcontinent and confirmed another time, how unexplored Sri Lanka is yet. Efforts on additional and more intensive sampling with light traps closer to remnant forest areas and not yet explored areas off the so far protected areas, may reveal unknown taxa but also complete the knowledge of the fauna in a more comprehensive way, covering the entire land surface of the Island. Therefore, we plan further field work and sampling effort.

\section{Acknowledgements}

Fieldwork for this study was partly funded by institutional funds of the ZFMK and by the German Academic Exchange Service (DAAD). S.R. was funded by the DAAD; S.P.B. was funded by the NIFS. We are thanking to N. Athukorala, D. Bopearachchi, A. Sathkunanathan and M. Tharmarajan of the NIFS for their support in the field. Further, we are grateful to Prof. S. Wijesundara, C. Lekamge and J. Amarasinghe for providing facility in the NIFS Arboretum. Furthermore, we are thankful to all Wildlife Rangers (Nuwara Eliya, Horton Plains), Regional forest officers (Kandy, Knuckles, Nuwara Eliya) who helped us to conduct the fieldwork. For providing research and collection permits to S.P.B, we thank the Department of Wildlife Conservation, Sri Lanka (permit no: WL/3/2/61/18), the Department of Forest Conservation, Sri Lanka (permit no: R\&E/RES/NFSRCM/2019-01), the Divisional Forest Office, Kandy, Sri Lanka (permit no: K/G/01/06/03).

\section{References}

Ahrens D. \& Fabrizi S. 2016. A Monograph of the Sericini of India (Coleoptera: Scarabaeidae). Bonn Zoological Bulletin 65: 1-355.

Fabrizi S. \& Ahrens D. 2014. A Monograph of the Sericini of Sri Lanka (Coleoptera: Scarabaeidae). Bonn Zoological Bulletin, Supplements 61: 1-124.

Eberle J., Fabrizi S., Lago P. \& Ahrens D. 2016. A historical biogeography of megadiverse Sericini another story out of Africa? Cladistics 33: 183-197.

Manuscript received: 24 August 2019

Manuscript accepted: 19 December 2019

Published on: 1 April 2020

Topic editor: Gavin Broad

Desk editor: Eva-Maria Levermann

Printed versions of all papers are also deposited in the libraries of the institutes that are members of the EJT consortium: Muséum national d'histoire naturelle, Paris, France; Meise Botanic Garden, Belgium; Royal Museum for Central Africa, Tervuren, Belgium; Royal Belgian Institute of Natural Sciences, Brussels, Belgium; Natural History Museum of Denmark, Copenhagen, Denmark; Naturalis 
Biodiversity Center, Leiden, the Netherlands; Museo Nacional de Ciencias Naturales-CSIC, Madrid, Spain; Real Jardín Botánico de Madrid CSIC, Spain; Zoological Research Museum Alexander Koenig, Bonn, Germany; National Museum, Prague, Czech Republic. 